\title{
PERGULATAN ALIRAN KEPERCAYAAN DALAM PANGGUNG POLITIK INDONESIA, 1950AN-2010AN: ROMO SEMONO SASTRODIHARDJO DAN ALIRAN KAPRIBADEN
}

\author{
Aryono \\ Majalah Historia \\ Jalan Jatibaru Raya Nomor 28, Tanah Abang, Jakarta Pusat \\ Alamat korespondensi: aryono1@gvmnetworks.com
}

Diterima/ Received: 2 March 2018; Disetujui/ Accepted: 29 March 2018

\begin{abstract}
This article discusses about the efforts of creeds religion flourished to maintain their existence since the 1950s until the late 2010's in Indonesia. Using historical method, this article found the interesting facts about the struggle of creeds religion in political stage of Indonesia. In 1953, for example, the Ministry of Religion Affairs noted that there were 360 groups protected by the government according on the Constitutional Law 1945 Article 29. After the tragedy of 1965, migration of members to the religions took place. When Soeharto became president, these groups was allowed to flourish. However, they got discrimination and always being watched. A new hope was arose in 2006, when the government issued Law No. 23/2006 about Population Administration, although it still requires to fill the religious column in national identity card (KTP). In the end 2017, the Constitutional Court issued a fatwa related to the status of religious column in KTP of the creeds religion. This condition also encompassed to Aliran Kapribaden's Romo Semono Sastrodiharjo in Purworejo, Central Java. This discrimination must be terminated, in the name of unity in diversity.
\end{abstract}

Keywords: Creeds Religion; Discrimination; Public Services.

\begin{abstract}
Abstrak
Artikel ini membahas mengenai upaya aliran kepercayaan yang tumbuh subur di Indonesia dalam mempertahankan eksistensinya dari 1950-an hingga 2010-an. Melalui penggunaan metode sejarah, artikel ini menemukan beberapa fakta menarik mengenai pergulatan aliran kepercayaan dalam panggung politik di Indonesia. Pada 1953 misalnya, Departemen Agama mencatat setidaknya terdapat 360 aliran kebatinan yang dilindungi oleh pasal 29 UUD 1945. Pasca-tragedi 1965, terjadi migrasi pengikut aliran kepercayaan ke dalam agama-agama resmi. Memang, pada awal Soeharto menjadi presiden, aliran kepercayaan dibiarkan tumbuh subur. Namun kemudian, mereka mengalami diskriminasi dan selalu diawasi. Harapan muncul pada 2006, saat pemerintah mengesahkan UU No. 23/2006 mengenai Administrasi Kependudukan, kendati masih mewajibkan mengisi kolom agama. Pada akhir 2017, Mahkamah Konstitusi mengeluarkan fatwa terkait status kolom agama di KTP para penghayat kepercayaan. Kondisi ini juga melingkupi Aliran Kapribaden yang didirikan oleh Romo Semono Sastrodijarjo di Purworejo, Jawa Tengah. Diskriminasi kepada penghayat kepercayaan harus sudah diakhiri, atas nama persatuan dalam keberagaman.
\end{abstract}

Kata Kunci: Aliran Kepercayaan; Diskriminasi; Layanan Publik. 


\section{PENDAHULUAN}

Indonesia adalah negara yang terdiri dari berbagai suku bangsa dan bahasa tersebar mulai dari Sabang sampai Merauke. Keberagaman yang ada di masyarakat Indonesia telah membentuk berbagai macam kebudayaan dan falsafah hidup masyarakat Indonesia. Salah satu unsur dari keberagaman bangsa Indonesia adalah keberagaman keagamaan. Pemerintah, mengacu pada Penetapan Presiden Nomor 1 Tahun 1965, hanya mengakui enam agama yang ada di Indonesia yaitu Islam, Kristen, Katolik, Hindu, Budha dan Konghucu yang dikukuhkan dengan UU Nomor 5 tahun 1969. Kelemahan regulasi ini adalah hanya menyebutkan agama yang berasal dari luar, dan tidak menyebutkan agama pribumi (Gaus, 2009: 225).

Di dalam sejarahnya, aliran kepercayaan pernah merasakan hidup aman dan nyaman dalam menjalankan kepercayaan yang diyakini dan dianut di Indonesia. Semua itu berubah cerita pilu saat terjadi peristiwa G30S 1965. Selepas peristiwa tragedi itu, eksistensi aliran kepercayaan (kebatinan) kerap disandingkan dengan Partai Komunis Indonesia (PKI). Akibat stigmatisasi dan hubungannya dengan tragedi 1965, maka terjadi eksodus besar-besaran kepindahan pengikut aliran kepercayaan (kebatinan) ke agama-agama resmi lainnya (Mulder, 1984: 7). Setelah Orde Baru tumbang, harapan baru muncul di kalangan penganut aliran kepercayaan (kebatinan) di Indonesia. Diskriminasi yang disematkan kepada mereka, perlahan mulai dikikis.

Puncak dari lepasnya diskriminasi tersebut adalah ketika pada Selasa, 7 November 2017, Mahkamah Konstitusi (MK) Republik Indonesia (RI) mengabulkan permohonan yang diajukan oleh Nggay Mehang Tana, Pagar Demanra Sirait, Arnol Purba cum suis dengan nomor perkara 97/PUU-XIV/2016. Permohonan tersebut terkait status kolom agama di Kartu Tanda Penduduk (KTP) dan Kartu Keluarga (KK) bagi Penghayat Kepercayaan. Pada putusannya itu, Majelis Hakim Mahkamah Konstitusi RI berpendapat bahwa kata 'Agama' dalam Pasal 61 ayat (1) dan Pasal 64 ayat (1) UU No. 24 Tahun 2013 tentang Perubahan Atas Undang-undang
No. 23 Tahun 2006 tentang Administrasi Kependudukan, bertentangan dengan UUD 1945 dan tidak mempunyai kekuatan hukum mengikat secara bersyarat sepanjang tidak termasuk penganut aliran kepercayaan. Putusan MK ini berarti, bahwa Penghayat Kepercayaan memiliki hak yang sama, seperti para penganut enam agama resmi yang ada di Indonesia dalam hal pencatatan status keagamaannya di Kartu Tanda Penduduk. Langkah ini menjadi langkah strategis yang ditempuh oleh MK dalam usaha menyatukan perbedaan antara aliran kepercayaan dan agama yang diakui oleh negara. Berdasar latar belakang tersebut, fokus kajian ini adalah mengenai pergulatan aliran kebatinan dalam panggung politik Indonesia pada 1950-an hingga 2010-an. Pembahasan akan fokus pada Aliran Kapribaden, sebuah kelompok aliran kebatinan di Purworejo, Jawa Tengah.

\section{METODE}

Sebagai tulisan sejarah, artikel ini ditulis menggunakan metode sejarah yang meliputi empat tahap, yakni pengumpulan sumber, kritik, interpretasi, dan penulisan sejarah (Gottschalk, 1983: 32). Sumber-sumber baik primer maupun sekunder yang digunakan dalam artikel ini disimpan dan diperoleh dari beberapa instansi yang berkompeten, seperti Arsip Nasional Republik Indonesia (ANRI), Perpustakaan Nasional (Perpusnas), Perpustakaan Depar temen Sejarah Fakultas Ilmu Budaya Universitas Diponegoro, dan beberapa koleksi pribadi yang dimiliki oleh Subagyo. Sumber lisan sebagai hasil dari wawancara juga dilakukan terhadap tokohtokoh utama Aliran Kapribaden.

\section{GELIAT ALIRAN KEPERCAYAAN DI PANGGUNG POLITIK NASIONAL}

Sebelum membahas lebih jauh mengenai aliran kebatinan di Indonesia, perlu memberi batasan terlebih dahulu mengenai agama dan kepercaya an. Parsudi Suparlan memberikan batasan mengenai definisi agama dan kepercayaan. Secara garis besar, agama yang dipunyai dalam masyarakat apa pun di dunia ini, termasuk Indonesia, terbagi dalam dua golongan yaitu 
founded religion atau yang disebut Agama Langit dan folk religion atau Agama Bumi yang disebut aliran kepercayaan keagamaan. Dalam kepustaka an antropologi dan sosiologi, kedua golongan agama tersebut dikenal dengan nama religion of great tradition -agama tradisi besar- dan religion of little tradition -agama tradisi kecil atau lokal (Suparlan, 1983: 3).

Kedua golongan tersebut pada hakikatnya memiliki prinsip yang sama yaitu memiliki petunjuk-petunjuk yang mengatur hubungan manusia dengan gaib, dengan sesama manusia, dan dengan alam. Bagian yang membedakan Agama Wahyu dan Agama Bumi yaitu pada Agama Wahyu dapat dijejaki eksistensinya dari seorang nabi atau tokoh; menentang magi dan mitologi; lebih individual dalam usaha membebaskan diri dari dosa setelah meninggal; dan subjektif. Sementara dalam Agama Bumi, asal eksistensinya samar-samar; menekankan fungsi untuk melayani masyarakat sehingga penuh magi dan mitologi (Suparlan, 1983: 4).

Di Indonesia, utamanya setelah kemerdekaan, persoalan agama dan kepercayaan menjadi satu masalah yang serius. Kata 'kepercayaan' yang dimaksud di sini merujuk pada ajaran pandangan hidup berkepercayaan kepada Tuhan YME yang tidak bersandar sepenuhnya kepada ajaran agama-agama yang diakui pemerintah Indonesia. Puncak dari benturan Agama dan Kepercayaan di Indonesia adalah saat pecah peristiwa G30S 1965, yaitu tuduhan komunis bagi para penganut kepercayaan, sehingga menimbulkan eksodus besar-besaran ke agama-agama yang diakui pemerintah.

Tumbuh suburnya aliran kepercayaan di Indonesia tidak bisa dilepaskan dari sosok Wongsonegoro. Politikus gaek ini saat kecil bernama R. M. Soenardi. Ia lahir di Surakarta, pada 20 April 1897 dari pasangan R. Ng. Gitodiprojo dan R.A. Soenartinah. Ayahnya adalah abdi dalem panewu dari Sri Susuhunan Pakubuwono X di Surakarta (Ensiklopedi Kepercayaan terhadap Tuhan Yang Maha Esa, 2003: 419). Wongsonegoro memiliki karier politik yang cemerlang. Saat muda, ia bergabung ke dalam Budi Utomo dan puncak kariernya adalah ketika ia berduet dengan Ali Sastro- amidjojo dalam mengelola kabinet periode $30 \mathrm{Juli}$ 1953-12 Agustus 1955.

Pada kurun 1950 hingga akhir 1960-an dalam catatan Departemen Agama 1953, seperti termaktub dalam Merayakan Kebebasan Beragama: Bunga Rampai Menyambut 70 Tahun Djohan Effendi, terdapat 360 aliran kebatinan di seluruh pulau Jawa. Payung hukum kemunculan aliran kepercayaan adalah pasal 29 UUD 1945, yang menyurat kata 'kepercayaan'. Kata 'kepercayaan', adalah buah pemikiran dari Wongsonegoro, salah satu anggota perancang UUD 1945. Ia mengusulkan kebebasan beribadat secara luas termasuk bagi kebatinan dalam segala bentuk dan isinya (Thaher, 2009: 380). Menurut Abdul Gafar Pringgodigdo pada Simposium Nasional Kepercayaan di Yogyakarta pada Nopember 1970, usul Wongsonegoro untuk mencantumkan pula kata kebatinan dalam pasal 29 UUD 45 diterima. Akan tetapi, dalam proses pembuatannya dicari kata lain yang lebih netral, sehingga digunakan kata kepercayaan seperti yang ada pada ayat 2 pasal 29 UUD 45 hingga sekarang (Heuken, 2005: 89).

Di pergaulan elite saat itu, Wongsonegoro dikenal kepeduliannya mengenai keberadaan aliran kepercayaan di masyarakat. Sekali waktu, di bekas kediaman Sukarno, Pegangsaan Timur Nomor 56, dihelat diskusi rutin pada malam bulan purnama. Kebetulan tema khusus pada 4 Desember 1952 itu adalah Agama dan Mistik. Panitia diskusi pun memilih Wongsonegoro sebagai moderator diskusi, karena ia dipandang sebagai satu tokoh yang paham dan dekat dengan aliran kepercayaan yang banyak bermunculan saat itu (Tim Buku Tempo, 2016: 119). Jejaring yang luas dan modal sebagai 'orang kuat' membuatnya dengan mudah menyelenggarakan perhelatan yang mempertemukan aliran-aliran kepercayaan di Semarang pada 19-21 Agustus 1955, yang kemudian menjadi kongres Kebatinan pertama. Pada kesempatan ini dibentuk pula Badan Kongres Kebatinan Indonesia (BKKI) dan Wongsonegoro pun terpilih sebagai ketuanya.

Wongsonegoro menegaskan bahwa pendirian BKKI ini dilandasi oleh suatu hal yang dalam Kongresnya di Semarang itu dinamakan 'Sepi ing Pamrih Rame ing Gawe' dan 'Memayu Hayuning Bawana', yang artinya Bekerja giat 
guna kepentingan umum, bangsa dan umat manusia dengan tidak berhasrat yang melebihi batas bagi diri dan golongannya sendiri (Maskan, 2002: 12). Sejak kongres pertama itu, hampir setiap dua tahun sekali BKKI rutin menghelatnya. Seperti Kongres Kebatinan Indonesia II di Surakarta pada 1956; Kongres Kebatinan Indonesia III pada 17-20 Juli 1958 di Jakarta; Kongres Kebatinan Indonesia IV pada 22-24 Juli 1960 Malang-Jawa Timur; dan Kongres Kebatinan Indonesia V pada 1-4 Juni 1963 di Ponorogo-Jawa Timur.

Pada 7-9 November 1970, Wongsonegoro sebagai mantan anggota BPUPKI, mengetuai simposium nasional Kepercayaan, Kebatinan, Kejiwaan, Kerohanian di Yogyakarta. Hasil dari simposium itu adalah kedudukan dan fungsi kebatinan, kejiwaan, serta kerohanian sejajar dengan agama. Sebulan kemudian, Desember 1970, Sekretariat Bersama (Sekber) Golkar membentuk Badan Koordinasi Karyawan Kerohanian, Kebatinan, Kejiwaan Indonesia (BK5I), yang kedudukannya setara dengan Persatuan Ulama Seluruh Indonesia. Cikal bakal BK5I adalah Badan Musyawarah Kebatinan, Kejiwaan dan Kerohanian (BMK3I) yang pada 1966 menjadi komponen Sekber Golkar.

Lalu pada 1971, BK5I menjadi Sekretariat Kerjasama Kepercayaan (SKK) sebagai wadah yang menghimpun seluruh paguyuban atau organisasi kepercayaan, dan diketuai Wongsonegoro serta R.S. Soekanto Tjokrodiatmodjo, mantan Kapolri pertama, sebagai sekretaris jenderal. Dalam musyawarah nasional di Yogyakarta dirumuskan pengertian istilah aliran kepercayaan yaitu semua kegiatan kejiwaan, kebatinan, kerohanian yang semuanya dihimpun dalam satu wadah SKK (Permadi, 1996: 55). Menjamurnya aliran kepercayaan mendapat sorotan wakil rakyat di parlemen terutama dari kalangan Islam. Menurut pengumuman Pengawas Aliran Kepercayaan Masyarakat (Pakem), pada April 1972 tercatat 217 aliran kebatinan dan 427 cabang kebatinan. Dari jumlah 217 aliran kebatinan, 188 di antaranya berasal dari Jawa Tengah, dan hanya 29 aliran saja berasal dari luar Jawa Tengah (Sou'yb, 1988: vii).
Seperti pada Sidang Umum 1973, Fraksi Partai Persatuan Pembangunan (F-PPP) sudah mengajukan keberatan atas usul dari Fraksi Karya Pembangunan (F-KP), Fraksi Angkatan Bersenjata Republik Indonesia (F-ABRI), dan Utusan Daerah mengenai pencantuman istilah 'Kepercayaan' di belakang kata Agama. Meski alot di parlemen, 'Kepercayaan' tetap dimuat dalam rumusan Garis-Garis Besar Haluan Negara (GBHN) 1973, dan fraksi Persatuan Pembangunan bisa menerima meski disertai catatan. Ide memasukkan aliran kepercayaan dalam GBHN 1973 ditengarai berawal dari hasil konferensi pekerja Golkar I, Maret 1972. Dalam konferensi itu menghasilkan resolusi bahwa Golkar ingin menyamakan kebatinan Jawa dengan kelima agama resmi di Indonesia. Resolusi itu kemudian dibawa ke rapat khusus DPP Golkar pada April 1972 (Cahyono, 1992: 127). Resolusi itu menjadi bahan masukan bagi Tim Penyiapan Bahan-bahan Sidang Umum MPR 1973. Aliran kebatinan pun masuk dalam naskah kerja GBHN yang disusun oleh tim kerja yang dipimpin Darjatmo, kepala staf Kekaryaan Hankam sekaligus karib Ali Murtopo. Dalam sidang MPR itu, F-KP mengajukan masalah kebatinan berdasarkan pasal 29 ayat 2 UUD 1945. F-KP memasukkan aliran kebatinan ke dalam 'kepercayaan terhadap Tuhan Yang Maha Esa'. Fraksi Partai Demokrasi Indonesia (F-PDI) tidak bereaksi atas usul itu, sedangkan F-PPP menolak keras.

Meski alot di parlemen, kepercayaan tetap dimuat dalam rumusan GBHN 1973 dengan modifikasi dari aliran kebatinan menjadi aliran kepercayaan. F-PPP bisa menerima hal itu meski disertai catatan (Sufyan, 2014: 45). Saat rapat paripurna ketiga, 16 Maret 1973, juru bicara dari Fraksi Persatuan Pembangunan, Chalid Mawardi, mengemukakan pendapat fraksinya. Menurutnya, dalam rangka pembinaan bangsa hendaknya juga aliran-aliran kepercayaan atau faham-faham keagamaan dapat kita tempatkan pada proporsinya, sehingga dapat dilakukan pembimbingan, pembinaan dan pengawasan agar aliran-aliran kepercayaan itu kembali kepada induk agamanya masing-masing serta berusaha mencegah perkembangan aliran kepercayaan 
yang bertentangan dengan Pancasila dan keyakinan beragama (CSIS, 1973: 56).

Walaupun mendapat kritik dari kalangan Islam, GBHN tetap memuat unsur 'Kepercayaan' dalam bagian Arah dan Kebijaksanaan Pembangunan. Arah kebijakan pemerintah pun diselaraskan dengan amanat GBHN, yaitu pembinaan kerukunan umat beragama dan kepercayaan. Setelah digariskan dalam GBHN, pemerintah melalui Departemen Agama berupaya mengatur dan mengawasi keberadaan para penghayat kepercayaan yang tumbuh di Indonesia. Pada 1975, Departemen Agama membentuk Badan Penelitian dan Pengembangan Agama. Di dalam badan penelitian tersebut, muncul organisasi bernama Pusat Penelitian dan Pengembangan Kehidupan Agama dan Kepercayaan Kepada Tuhan Yang Maha Esa yang dikukuhkan dengan Keputusan Menteri Agama Nomor 18 Tahun 1975.

Isu aliran kepercayaan masih menjadi perdebatan panas di kalangan wakil rakyat. Pada Sidang Umum 1978, pemerintah kembali memasukan pembinaan aliran kepercayaan ke dalam GBHN. Sidang MPR/ DPR akhir Maret 1978 berlangsung panas, baik di dalam maupun di luar komplek gedung MPR/DPR. Aksi teror pun membayangi ibukota Jakarta. Senin 20 Maret 1978, sebuah mobil pick-up merek Peugeot dengan nomor polisi B 9679 AT bermuatan dua drum berisi bensin ditinggalkan begitu saja di depan Hotel Indonesia (HI). Rupanya, pada lubang drum sudah terpasang sumbu. Api sudah menyala di ujungnya, siap merembet dan meledak. Namun beruntung, aksi teror itu berhasil digagalkan para sopir yang ada di sekitar bundaran HI. Api berhasil dipadamkan.

Panglima Pelaksana Khusus Kopkamtib Daerah Jakarta Raya (Laksusda Jaya), Norman Sasono, beberapa hari kemudian memberi keterangan pers yang disiarkan oleh Televisi Republik Indonesia (TVRI). Sekitar 39 orang ditangkap oleh tim dari Laksusda Jaya atas tuduhan ancaman teror selama berlangsungnya SU MPR 1978. Selanjutnya, seperti ditulis oleh Panji Masyarakat 1 April 1978, jenderal berbintang dua itu menyebut nama Abdul Kadir Jaelani, ketua umum Gerakan Pemuda Islam (GPI) sebagai otak teror dan bertujuan mendirikan negara Islam. Kondisi panas di luar gedung, "merembet" pula ke dalam gedung parlemen. Salah satu agenda SU MPR 1978 adalah menetapkan rancangan Garis-garis Besar Haluan Negara. Rancangan GBHN itu disusun oleh pemerintah untuk digodok dalam rapat fraksi sebelum rapat disahkan dalam rapat paripurna. Bahan untuk sidang MPR tersebut disusun oleh sebuah tim dengan susunan Sudharmono (ketua), JB Sumarlin (wakil), Ismail Saleh (sekretaris), dan delapan anggota lain seperti Kartakusumah, A. Wiranatakusumah, Subarkah, Ali Murtopo, Daryatmo, Majid Ibrahim, Kartidjo, serta Murdiono. Dalam rancangan itu, pemerintah memuat pembahasan aliran kepercayaan kepada Tuhan. F-PPP menolak hal tersebut (Patmono dalam Balitbang DGI, 2003: 486).

Pada rapat Komisi A, F-PPP tidak dapat menerima rancangan GBHN dari pemerintah yang mencantumkan aliran kepercayaan dalam suatu dokumen konstitusional seperti GBHN. Jika dipaksakan, hal ini akan mengganggu stabilitas dan persatuan nasional. Yusuf Syakir yang ditunjuk sebagai juru bicara Fraksi Persatuan di Komisi A, pada akhir pembacaan keputusan F-PPP, menyatakan bahwa fraksinya akan melakukan walk-out. Ia mengatakan bahwa kepercayaan terhadap Tuhan Yang Maha Esa yang diartikan sebagai kepercayaan yang berdiri di luar agama serta mendapat perlakuan yang sama, seperti tercantum dalam naskah rancangan GBHN adalah bertentangan dengan Pancasila dan UUD 1945 (Panji Masyarakat, 1 April 1978). Meski F-PPP memutuskan walk-out, rapat Komisi A akhirnya tetap memutuskan bahwa kepercayaan terhadap Tuhan bukan merupakan agama dan pembinaan kepada para penghayat kepercayaan itu perlu untuk mencegah supaya tidak mengarah pada pembentukan agama baru. Dalam rapat paripurna, F-PPP kembali melakukan walk-out ketika sidang akan mengesahkan aliran kepercayaan terhadap Tuhan dalam GBHN 1978. Pengakuan atas aliran kepercayaan dalam batang tubuh naskah GBHN 1978 dimuat pada bagian Modal Dasar Pembangunan Nasional, Wawasan Nusantara, Arah Pembangunan Jangka Panjang, dan Sasaran Pembangunan Jangka Panjang. 
Penyebutan aliran kepercayaan yang berdampingan dengan agama-agama resmi, tulis Martin van Bruinessen, adalah ungkapan implisit pemerintah yang memberikan pengakuan formal kepada aliran kepercayaan ini sebagai agama tersendiri. Kyai Bisri Syansuri, presiden Majelis Syuro PP dari Nahdlatul Ulama yang dikenal kurang memiliki naluri politik dan tidak berkompromi menyangkut prinsip agama, memandangnya sebagai ancaman terhadap status Islam sebagai agama dan memprotesnya dengan keras (van Bruinessen, 1994:107). Dalam bukunya tersebut, Martin van Bruinessen mencatat bahwa kepekaan umat Islam dapat dimengerti dengan lebih baik jika orang ingat bahwa Soeharto sendiri dan para penasihat terdekatnya dipercaya sebagai penganut aliran kepercayaan dan tidak simpatik terhadap Islam skripturalis.

Pasca-sidang umum 1978 yang menelurkan Ketetapan MPR No. IV/MPR/1978 tentang GBHN, pemerintah segera mengeluarkan Keputusan Presiden No. 40 Tahun 1978 mengenai pengawasan aliran kepercayaan beralih dari Departemen Agama ke Departemen Pendidikan dan Kebudayaan dengan membentuk Direktorat Pembinaan Penghayat Kepercayaan (PPK) Terhadap Tuhan Yang Maha Esa di bawah pimpinan Direktorat Jenderal Kebudayaan. Tugas pokok PPK baru selesai setahun kemudian, 30 Juni 1979, setelah Daoed Joesoef selaku Menteri Pendidikan dan Kebudayaan menandatangani surat keputusan nomor 0145/O/79 yang berisi empat tugas pokok Direktorat PPK seperti (1) mempersiapkan perumusan kebijakan teknis pembinaan penghayat kepercayaan sesuai kebijakan teknis Dirjen, (2) menyusun materi dan program pembinaan penghayat kepercayaan, (3) menyelenggarakan bimbingan dan penyuluhan serta melaksanakan publikasi dan dokumentasi pelaksanaan pembinaan penghayat kepercayaan, dan (4) melakukan penelitian atas pelaksanaan kegiatan pembinaan penghayat kepercayaan. Bahkan, TVRI juga memberi ruang bagi penghayat kepercayaan dalam acara "Mimbar Kepercayaan".

Pada sidang kabinet terbatas bidang politik dan keamanan 27 September 1978, permasalahan agama dalam perkawinan menjadi pembahasan tersendiri. Alamsjah Ratu Prawiranegara, Menteri Agama sekaligus mantan jendral- menekankan kepada stabilitas nasional. Ia pun mengeluarkan SK Menteri Agama No. 70 dan 77 Tahun 1978 (tentang Penyiaran Agama dan Bantuan Luar Negeri untuk Lembaga Agama). Langkah ini didukung oleh Soeharto hingga puncaknya pada 10 Oktober 1978, Alamsjah menghadap Soeharto ke Bina Graha. Ia mendapat pengarahan mengenai SK Menteri Agama No. 70 dan 77 Tahun 1978 (tentang Penyiaran Agama dan Bantuan Luar Negeri untuk Lembaga Agama) dan penegasan bahwa perkawinan di Indonesia cuma ada dua: menurut tata cara agama dan catatan sipil. Tidak lama setelah Soeharto berbicara di depan menteri Agama, Menteri Dalam Negeri Amir Machmud mengeluarkan surat edaran bernomor $477 / 74054$ bertanggal 18 November 1978 kepada semua gubernur dan bupati/walikota se-Indonesia mengenai petunjuk pengisian kolom 'agama' dan pengakuan lima agama saja dari pemerintah seperti Kristen/ Protestan, Katholik, Islam, Budha, dan Hindu.

Setelah keluar SK Mendagri mengenai keharusan mengisi kolom agama, menteri Agama juga melakukan hal serupa. Surat menteri Agama bertanggal 17 Juli 1980 itu menerangkan bahwa jika ada penghayat kepercayaan yang membubuhi tanda garis mendatar pada kolom agama, akan dicap sebagai tidak beragama. Penyebutan agama dalam KTP bagi para penghayat kepercayaan yang ditulis dengan tanda (-) yang berarti mereka itu yang bersangkutan adalah tidak beragama, padahal semula mereka itu adalah pemeluk agama yang sah. Bukan itu saja, masih dalam surat yang sama, jika ada penghayat kepercayaan yang mengajak orang beragama lain untuk mengikutinya maka dihadang dengan pasal 156 a KUHP, juga dalam UU Nomor 1 PNPS 1965 pasal 4, dengan ancaman 5 tahun penjara (Arsip Menteri Agama Nomor B VI/5996/1980).

Kejaksaan Agung, pada 1984, mengeluarkan surat keputusan No Kep108/J.A/5/1984 tentang Pembentukan Tim Koordinasi Aliran Kepercayaan Masyarakat (Pakem). Tujuan utama tim ini, seperti termuat dalam konsiderannya, mengambil langkahlangkah atau tindakan terhadap aliran-aliran kepercayaan yang dapat membahayakan 
masyarakat dan negara. Pengawasan lain terhadap aliran kepercayaan, adalah terbitnya UU No 8 Tahun 1985 mengenai organisasi kemasyarakatan. Setelah terbit UU Ormas tersebut, terdapat 250 organisasi yang terdaftar sebagai aliran kepercayaan (Sutarto, 2007: 44). Organisasi penghayat Kapribaden sendiri, seperti termuat di www.kapribaden.org, sudah terdaftar di Departemen Dalam Negeri dengan pengumuman pemerintah tentang organisasi kemasyarakatan yang sah di tingkat nasional, bernomor 324.

Pada 1991, pemerintah bersama DPR mengesahkan UU Kejaksaan No. 5/1991, yang isinya memperluas wewenang kejaksaan tidak hanya sebagai penuntut dan melakukan sosialisasi hukum saja, melainkan juga bertugas di bidang ketertiban dan ketentraman umum. PascaReformasi 1998, Tim Pakem masih juga menjadi momok bagi aliran kepercayaan. Pemerintahan yang berkuasa pasca-1998 tetap membutuhkan Tim Pakem tidak hanya untuk mengawasi aliran kepercayaan atau kebatinan saja, tetapi juga untuk mengawasi sekte-sekte di dalam agama 'resmi' yang mempunyai potensi melakukan penyimpangan atau bertentangan dengan mainstream (Sihombing, dkk., 2008: 43). Angin segar bagi aliran kepercayaan sebenarnya muncul pada masa pemerintahan Abdurrahman Wahid yang singkat. Jaksa Agung pada masa tersebut mencabut SK Jaksa Agung yang melarang Saksi Yehova karena sudah tidak sesuai dengan prinsip demokrasi.

Pada 2006, pemerintah mengesahkan Undang-Undang Nomor 23/2006 mengenai Administrasi Kependudukan (Adminduk). Setahun kemudian keluar peraturan pemerintah (PP) Nomor 37 Tahun 2007 mengenai Pelaksanaan UU Adminduk 2006. Kedua aturan formal tersebut cukup memberi harapan bagi kemerdekaan penghayat kepercayaan. Harapan yang paling menggembirakan bagi penghayat kepercayaan tentu saja dengan munculnya Peraturan Menteri Pendidikan dan Kebudayaan (Permendikbud) Nomor 27 Tahun 2016 mengenai layanan pendidikan kepercayaan terhadap Tuhan Yang Maha Esa pada satuan pendidikan yang ditandatangani Anies Baswedan. MLKI yang merupakan himpunan organisasi penghayat kepercayaan yang sudah diakui pemerintah mulai bekerja mempersiapkan kurikulum pendidikan bagi penghayat kepercayaan, bekerja sama dengan Pusat Kurikulum dari Kementrian Pendidikan dan Kebudayaan. Bukan hanya kurikulum, namun MLKI juga mempersiapkan pengajar-pengajar dari kalangan penghayat kepercayaan untuk nanti bisa mengajar baik dari jenjang sekolah dasar hingga atas. Selain merancang kurikulum, MLKI bekerjasama dengan Badan Nasional Sertifikasi Profesi (BNSP), Badan Koordinasi Sertifikasi Profesi (BKSP) dan Akademisi juga menyelenggarakan peningkatan kompetensi calon penyuluh dari masing-masing organisasi penghayat kepercayaan.

Pada medio Januari 2018, Majelis Ulama Indonesia (MUI) menggelar konferensi pers tentang sikap MUI putusan Mahkamah Konstitusi Nomor Perkara 97/PUU-XIV/2016, mengenai aliran kepercayaan. Ada delapan hal yang menjadi catatan MUI yaitu sebagai berikut: (1) MUI sangat menyesalkan putusan MK tersebut, putusan MK dinilai kurang cermat dan melukai perasaan umat beragama, khususmya umat Islam Indonesia, karena putusan tersebur berarti telah mensejajarkan kedudukan agama dengan aliran kepercayaan; (2) MUI berpandangan bahwa putusan MK tersebut menimbulkan konsekuensi hukum dan berdampak pada tatanan kehidupan sosial kemasyarakatan, serta merusak terhadap kesepakatan kenegaraan dan politik yang selama ini sudah berjalan dengan baik; (3) MUI berpendapat seharusnya MK dalam mengambil keputusan yang memiliki dampak strategis, sensitif, dan menyangkut hajat hidup orang banyak, membangun komunikasi dan menyerap aspirasi yang seluas-luasnya kepada masyarakat dan pemangku kepentingan, sehingga dapat mengambil keputusan secara objektif, arif, bijak dan aspiratif; (4) MUI menghormati perbedaan agama, keyakinan, dan kepercayaan setiap warga negara, karena hal tersebut merupakan implementasi dari Hak Asasi Manusia (HAM) yang dilindungi oleh negara, sesuai peraturan perundang-undangan yang berlaku; (5) MUI sepakat bahwa pelaksanaan pelayanan hak-hak sipil warga negara di dalam hukum dan 
pemerintahan tidak boleh ada perbedaan dan diskriminasi, sepanjang hal tersebut sesuai dengan ketentuan peraturan perundangundangan; (6) Terkait dengan hak-hak sipil sebagai warga negara, pembinaan warga penghayat kepercayaan agar tetap berada di bawah Kementerian Pendidikan dan Kebudayaan, sebagaimana yang selama ini telah berjalan dengan baik; (7) Oleh karena putusan MK sesuai konstitusi, bersifat final dan mengikat (final and binding), maka MUI mengusulkan kepada pemerintah agar kepada penghayat kepercayaan diberikan KTP Elektronik yang mencantumkan kolom kepercayaan, tanpa ada kolom agama; (8) Pembuatan KTP Elektronik untuk penghayat kepercayaan tersebut hendaknya dapat segera direalisasikan untuk memenuhi hak warga negara yang masuk kategori penghayat kepercayaan.

\section{ROMO SEMONO SASTRODIHARDJO DAN ALIRAN KAPRIBADEN}

Salah satu dari sekian banyak aliran kepercayaan yang tumbuh, berkembang, dan memiliki banyak pengikut di Indonesia adalah Aliran Kapribaden. Aliran ini mulai dikembangkan oleh Romo Semono Sastrohadijojo di Purworejo. Mulanya, Semono adalah anggota Angkatan Laut RI yang bertugas di Surabaya sejak 1950-an. Selama hidupnya, Semono menikah dua kali. Istri pertamanya, Ngarinem, meninggal terlebih dulu tanpa meninggalkan keturunan. Ia kemudian menikahi Tumirin, yang juga selama hidup tidak memiliki anak. Perawakan Romo Semono digambarkan tinggi tegap, memakai blangkon khas Yogya, dengan atasan surjan, bawahan batik, lengkap dengan keris (Wawancara dengan Subagiyo, 22 Januari 2018. Ia adalah penerus Romo Semono Sastrohadijojo).

Terdapat dua versi mengenai asal-usul sosok ini. Versi pertama menyatakan bahwa, Semono lahir pada Jumat Pahing, 12 Rabiulawal 1900 di Gunung Damar, Desa Kalinongko, Kecamatan Loano, Kabupaten Purworejo. Versi pertama ini juga menyebutkan bahwa ia merupakan anak keempat dari tujuh bersaudara keluarga Kasandikromo, seorang petani kecil yang hidup sederhana. Kondisi keluarga yang sederhana inilah yang membentuk Semono terbiasa menjalani laku prihatin (Widodo, 2002: 48). Versi kedua menyatakan bahwa Semono merupakan anak pungut dari keluarga Kasandikromo. Menurut versi ini, keluarga Kasandikromo menemukan bayi kecil Semono dan mengasuhnya dengan sepenuh hati, karena mereka belum dikaruani anak laki-laki. Anak lakilaki yang mereka temukan dan diberi nama Semono itu, diyakini sebagai trah Mataram. Atas keyakinan tersebut, keluarga Kasandikromo meyakini, suatu saat Semono akan menjadi orang besar dan membawa perubahan yang besar dalam keluarga (Widodo, 2002: 48).

Sejak kecil Semono terbiasa melakukan laku prihatin. Selain karena kondisi ekonomi keluarga yang sulit, ia memang menyenangi dunia mistik Jawa. Pada usia 14 hingga 17 tahun, ia juga telah mulai melakukan tapa brata, yaitu samadi di Goa Singobarong di Pulau Nusakambangan (Widodo, 2002: 49). Tapa brata terus ia lakukan hingga mendapatkan wahyu untuk mengajarkan ajaran Kapribaden pada tahun kembar (55), yakni 1955. Menurut para pengikutnya, Semono telah mijil atau lahir kembali pada 13 November 1955, tepat pada pukul 16.05. "Ingsun Mijil, arso nyungsang bawono balik, arso nggelar jagat anyar, anggulung jagad lawas (saya lahir kembali, memutar balik dunia, menata jagad baru, menutup jagad lama)", ujar Subagiyo menirukan ucapan Semono. Lima tahun setelah peristiwa mijil itu, Semono mundur dari dinas ketentaraan dengan pangkat terakhir kapten marinir dan kembali ke kampung halamannya di daerah Sejiwan, Purworejo. Sejak tinggal di Sejiwan, Semono menerima orang untuk berobat atau hanya menerima nasihat, termasuk Subagiyo kecil bersama ayahnya yang naik sepeda dari Banyu Urip ke Sejiwan. Inti ajaran Kapribaden yang diajarkan Semono terhadap pengikutnya adalah mengenai bagaimana manusia menjalani kehidupan, yang terangkum dalam dua ajaran utama, yaitu Panca Gaib dan Laku. Perlahan, sejak 1955, pengikut Semono semakin bertambah, bahkan mulai datang dari luar Purworejo.

Pada 1960-an, saat Partai Komunis Indonesia (PKI) masih menjadi partai resmi di Indonesia, partai belambang palu arit ini juga 
banyak menjadi tempat bagi bernaungnya para penganut kebatinan. Sejak peristiwa 1965 meletus, banyak padepokan dari gerakan kebatinan atau aliran kepercayaan yang menjadi tempat persembunyian anggota-anggota PKI. Salah satu yang menjadi pemberitaan adalah serangan tentara terhadap padepokan $M b a h$ Suro di Desa Nginggil yang kemudian dikenal dengan sebutan Mbah Suro Nginggil, di Kawedanan Randublatung, Blora. Mbah Suro memiliki nama asli Mulyono Surodihardjo, mantan kepala desa di salah satu kelurahan daerah Randublatung. Ia menikah dua kali, dan tidak memiliki anak. Menurut M. R. Ma'roef, seorang mahasiswa Fakultas Paedagogik UGM Yogyakarta yang pernah melakukan tugas penelitian di Randublatung pada September 1963, mbah Suro saat itu masih berumur 40 tahun. Ia berciri fisik memiliki jenggot panjang, perawakannya kurus tinggi, mata redup, selalu mengenakan setelan baju hitam dan iket, serta selalu bertopang tongkat. Mbah Suro dikenal sebagai seorang dukun. Menurut Ma'roef, setiap orang yang datang kepadanya harus membawa sebungkus rokok kretek; seikat kembang; dan uang sebesar 2,75 rupiah atau seringgit setalen. Selain sebagai dukun, ia pun membangun sebuah aliran kepercayaan yang bernama Djawa Dipa.

Sebelum Gerakan September Tigapuluh (Gestapu) 1965 meletus, mbah Suro berafiliasi dengan PKI. Tanda palu arit terpampang besar di muka rumahnya. Komplek rumahnya berada di tengah hutan jati. Dibutuhkan waktu sekitar dua jam untuk keluar dari komplek mbah Suro (Pandji Masyarakat, April 1967). Pada 1967, pengikut mbah Suro Nginggil semakin banyak. Pangdam VII/ Diponegoro pun memerintahkan untuk menutup padepokan itu. Upaya tersebut dilakukan oleh Kompi Tanjung, salah satu kompi dalam RPKAD yang dikirim ke Jawa Tengah. Panglima Daerah Militer terpaksa memerintahkan agar penutupan dilakukan dengan kekerasan karena jalan damai sudah tertutup. Akhirnya Kompi Tanjung menyerbu padepokan mbah Suro (Subroto, 2009: 143-144).

Pasca-tragedi 1965, banyak aliran kepercayaan menjadi sasaran tembak. Stigmatisasi sebagai pengikut PKI yang atheis, mengakibatkan migrasi pengikut aliran kepercayaan ke agama-agama resmi. Tragedi 1965 mewariskan stigma terhadap aliran kepercayaan atau kebatinan atas tuduhan merupakan bagian dari komunis. Padahal tuduhan tersebut tidak ada bukti atau fakta yang nyata. Bahkan sebaliknya, Aliran Kebatinan dalam perjalanannya kemudian dilarang dan dibekukan oleh Tim Pakem pasca-tragedi 1965. Pelarangan dan pembekuan tersebut diikuti oleh Tim Pakem di beberapa daerah seperti di Majalengka, Sumedang, dan Subang Jawa Barat (Sihombing, dkk., 2008: 30). Setelah Soeharto resmi menjadi presiden, beberapa aliran kepercayaan terutama dari Jawa dibiarkan tumbuh subur. Hal ini tidak dapat dilepaskan dari kepribadian Soeharto yang kental dengan karakter kejawen dan klenik. Ditambah, asisten pribadinya yang bernama Soedjono Humardhani, disebut pula 'Dukun Jepang' karena kedekatannya dengan Jepang, yang juga menyukai klenik.

Puncaknya adalah peristiwa pada sebuah pagi pada minggu kedua Mei 1967. Saat itu, Padepokan Romo Semono di Loano, Purworejo dipenuhi tentara. Mereka melakukan penggerebekan di padepokan itu karena adanya dugaan pelarian orang-orang PKI yang menyusup ke sana. Para tentara ini berasal dari kesatuan yang ada di Yogyakarta dan Resimen Para Komando Angkatan Darat (RPKAD). Dari temuan para tentara, dikumpulkan sejumlah surat yang diindikasikan sebagai bagian dari gerakan politik yang dilakukan oleh orang-orang PKI ke dalam kelompok aliran kepercayaan seperti yang dimiliki oleh Romo Semono di Purworejo. Mereka pun memeriksa 112 orang yang kebetulan ada di padepokan tersebut. Selain itu, para tentara ini juga menyita uang sebesar 40 ribu rupiah. Berbeda dari penyerangan militer terhadap padepokan mbah Suro, pada peristiwa tersebut, tidak terjadi perlawanan meski tentara telah bersiap dengan senjata lengkap menghadapi segala kemungkinan. Pada penggerebakan tersebut, tidak ditemukan senjata yang disita, hanya beberapa surat pusaka atau wasiat dari Romo Herutjokro, nama lain Romo Semono (Minggu Pagi, 16 Mei 1967).

Semono Sastrohadidjojo rupanya memiliki firasat tajam atas situasi politik dalam 
negeri setelah sidang umum 1978. Sebagai sesepuh bagi penganut Aliran Kapribaden, ia segera bertindak taktis. April 1978, ia mengirim pesan tertulis kepada lima pengikut utamanya, bahwa Kapribaden harus berbentuk organisasi. Pesan tersebut disampaikan kepada Wahyono Rahardjo, Hartini Wahyono, Soehirman, S. Parmin, dan Sakir (http://www.kapribaden.org, diakses 2 Februari 2018). Menurut penuturan Suprih Suhartono, Ketua Umum Organisasi Penghayat Kepercayaan Kapribaden saat itu semua penghayat kepercayaan harus membuat organisasi, termasuk Kapribaden. Tujuan dari pembentukan organisasi ini adalah memudahkan pemerintah dalam melakukan pengawasan. Organisasi Paguyuban Penghayat Kapribaden secara resmi terdaftar sesuai dengan UndangUndang Nomor Tahun 1985, Peraturan Pemerintah Nomor 18 tahun 1986, dan Permendagri Nomor 5 tahun 1986 (Widodo, 2002: 86).

Saat Orde Baru hanya menerima lima agama resmi, yakni Islam, Kristen, Katholik, Hindu, dan Budha, aliran kepercayaan semakin tidak mendapatkan tempat. Akibat paling jelas dari hal ini adalah pengisian kolom agama dalam Kartu Tanda Penduduk (KTP) yang tidak boleh kosong. Hal ini pula yang menyebabkan jumlah penganut agama resmi, terutama Islam, mengalami peningkatan dengan ditandai oleh perpindahan para penganut aliran kepercayaan kepada salah satu agama resmi negara. Banyak penganut aliran kepercayaan mengakui bahwa meskipun mereka mengisi kolom agama, Islam misalnya, pada KTP, namun, mereka merasa seperti membohongi diri (Wawancara dengan Subagiyo, 22 Januari 2016). Oleh karena itu, meskipun tampaknya Orde Baru memberi angin segar pada tumbuhnya aliran kepercayaan, era Orde Baru dirasa sangat berat bagi para penghayat kepercayaan. Meskipun demikian, mereka berusaha mengikuti segala aturan yang ada (Wawancara dengan Suprih Suhartono, 22 Januari 2017. Ia adalah juga salah satu anggota presidium Majelis Luhur Kepercayaan Indonesia (MLKI) periode 2014-2019).

Lebih lanjut, Suprih menuturkan bahwa pasca-Reformasi, kondisi telah berubah. Saat ini, bahkan jika ada pemerintah daerah yang tidak melayani penghayat kepercayaan, misalnya kesulitan mengosongkan kolom agama dalam KTP akan dikenakan sanksi dari pusat. Kegiatan mediasi antara warga penghayat dengan pemerintah kabupaten atau provinsi secara aktif dibantu oleh organisasi penghayat setempat. Sosialisasi mata pelajaran kepercayaan juga sudah dimulai di Jawa Tengah dan kemudian di Jawa Timur. Segenap perangkat yang dimulai dari materi, kurikulum, dan penyuluh juga sedang disiapkan. Salah satu sekolah yang sudah mulai menerapkan pendidikan bagi penghayat kepercayaan adalah SMKN 7 Semarang. Hal itu bermula dari siswa bernama Zulfa Nur Rohman yang tidak dapat naik kelas XII karena tidak mengikuti Pelajaran Agama Islam selama dua semester. Kabar pun menyebar. Akhirnya, setelah proses mediasi antara MLKI-Dinas Pendidikan Kota-dan pihak SMKN 7 Semarang, Zulfa Nur Rohman mendapat haknya untuk mendapat pengajaran materi penghayat kepercayaan dari dua orang petugas yang ditugasi MLKI. Namun, di tengah eksistensi penghayat yang semakin cerah, hambatan kembali mendera aliran kebatinan saat Menteri Dalam Negeri mengakomodasi usulan MUI untuk membedakan KTP antara yang beragama dan yang berkepercayaan. Hal ini tentu menjadi keberatan bila dilaksanakan. Endang Retno Lastani, Sekjen Dewan Musyawaran Pusat (DPP) Majelis Luhur Kepercayaan Kepada Tuhan YME Indonesia (MLKI), menyatakan bahwa pembedaan KTP semacam itu seolah-olah menciptakan warga negara level satu bagi KTP beragama, dan warga negara level kedua bagi KTP berkepercayaan.

\section{SIMPULAN}

Sepertinya, masalah agama dan kepercayaan masih belum selesai. Pemerintah sebagai pengayom harus berada dalam posisi melindungi setiap warga negara. Melihat perkembangan ke depan, persoalan status kolom agama di KTP akan kembali ramai. Perlu ada sinergi antara elite agama resmi dan perwakilan penghayat aliran kepercayaan dalam satu meja yang adil dengan perantaraan pemerintah. Bagaimanapun juga, keberagaman termasuk agama dan kepercayaan harus dipandang sebagai pendorong dan 
pemersatu kekuatan-kekuatan sosial dan moral dalam usaha menghadapi perubahan di masa yang akan datang.

\section{REFERENSI}

Arsip Menteri Agama Nomor B VI/5996/1980. Balitbang DGI Panitia Penerbitan Buku Kenangan Prof. DR. Olaf Herbert Schumann. (2003). "Agama dalam Dialog: Pencerahan, Pendamaian, dan Masa Depan. Punjung Tulis 60 tahun Prof. Dr. Olaf Herbert Schumann”. Jakarta: Gunung Mulia

Cahyono, H. (1992). Peranan Ulama dalam Golkar 1971-1980: dari Pemilu sampai Malari. Jakarta: Pustaka Sinar Harapan.

CSIS (1973). Analisa Sidang Umum MPR-RI 1973. Jakarta: CSIS.

Gaus, Ahmad A. F. (2009). Sang Pelintas Batas: Biografi Djohan Effendi. Jakarta: Penerbit Buku Kompas.

Gottschalk, L. (1983). Mengerti Sejarah, terjemahan Nugroho Notosusanto. Jakarta: BP UI.

Heuken, A. (2005). Ensiklopedi Gereja: K-KI. Jakarta: Yayasan Cipta Loka Caraka.

Http://www.kapribaden.org/, diakses 2 Februari 2018.

Maskan (2002). Tokoh Wongsonegoro. Jakarta: Proyek Pemanfaatan Kebudayaan, Direktorat Tradisi dan Kepercayaan, Deputi Bidang Pelestarian dan Pengembangan Budaya, Badan Pengembangan Kebudayaan dan Pariwisata.

Minggu Pagi, 16 Mei 1967.

Mulder, N. (1984). Kebatinan dan Hidup Seharihari Orang Jawa: Kelangsungan dan Perubahan Kulturil. Jakarta: Gramedia.

Pandji Masyarakat, April 1967.

Panji Masyarakat, 1 April 1978.

Permadi, K. (1996). Mengenal dan Mendalami Budaya Spiritual. Jakarta: Departemen Pendidikan dan Kebudayaan, Direktorat Pembinaan Penghayat Kepercayaan Terhadap Tuhan YME.

Sihombing, U. P. dkk. (2008). Menggugat Bakor Pakem: Kajian Hukum terhadap
Pengawasan Agama dan Kepercayaan di Indonesia. Jakarta: The Indonesian Legal Resource Center (ILRC).

Sou'yb, J. (1988). Aliran Kebatinan (Mistik) dan Perkembangannya. Jakarta: Rimbow.

Subroto, Hendro. (2009). Sintong Panjaitan: Perjalanan Seorang Prajurit Para Komando. Jakarta: Penerbit Buku Kompas. Sufyan, F. H. (2014). Sang Penjaga Tauhid: Studi Protes Tirani Kekuasaan 1982-1985. Yogyakarta: Deepublish.

Suparlan, P. dkk. (1983). Berbagai Kepercayaan di Indonesia (Suatu Studi Pendahuluan). Jakarta: Direktorat Sejarah dan Nilai Tradisional Departemen P dan K.

Sutarto, A. (2007). "Becoming a True Javanese: A Javanese View of Attempts at Javanization," Indonesia and the Malay World, Vol. 34 (1).

Thaher, E. P. (2009). Merayakan Kebebasan Beragama: Bunga Rampai Menyambut 70 Tahun Djohan Effendi. Jakarta: Penerbit Buku Kompas.

Tim Buku Tempo (2016). Seri Tempo: Wahid Hasyim (Tokoh Islam di Awal Kemerdekaan). Jakarta: KPG.

van Bruinessen, M. (1994). NU: Tradisi, Relasirelasi Kuasa, Pencarian Wacana Baru. Yogyakarta: LkiS.

Widodo (2002). "Dari Perdukunan Herucakra Hingga Paguyuban Penghayat Kapribaden (Studi tentang Perkembangan Sebuah Aliran Kepercayaan terhadap Tuhan Yang Maha Esa di Purworejo Tahun 19581994)”. Skripsi pada Jurusan Sejarah Fakultas Sastra Universitas Diponegoro, Semarang.

\section{DAFTAR INFORMAN}

Wawancara dengan Subagiyo, Ketua Penghayat Kapribaden cabang Purworejo.

Wawancara dengan Endang Retno Lastani, Sekjen Dewan Musyawaran Pusat MLKI.

Wawancara dengan Suprih Suhartono, Ketua umum organisasi penghayat kepercayaan Kapribaden. 